\title{
PENENTUAN TEKNOLOGI PROSES PEMBUATAN GAMBIR MURNI DAN KATEKIN TERSTANDAR DARI GAMBIR ASALAN
}

\section{Determination of Process Technology on Making of Pure Gambier and Standardized Catechin from Raw Gambier}

\author{
Gustri Yeni ${ }^{1, \star}$, Khaswar Syamsu ${ }^{2}$, Etik Mardliyati ${ }^{3}$, dan Hendri Muchtar ${ }^{1}$ \\ 1 Balai Riset dan Standardisasi Industri Padang JI. Raya LIK No. 23 Ulu Gadut Padang 25164, Indonesia \\ 2 Departemen Teknologi Industri Pertanian, Fakultas Teknologi Pertanian, \\ Institut Pertanian Bogor, Darmaga, Bogor 16680, Indonesia \\ 3 Pengembangan Formula dan Sediaan Farmasi, Pusat Teknologi Farmasi dan Medika, \\ BPPT Kawasan Puspiptek Serpong, Tangerang Selatan, Banten 15314, Indonesia \\ *e-mail: guszen@yahoo.com
}

Diterima: 4 Mei 2017, revisi akhir: 14 Juni 2017 dan disetujui untuk diterbitkan: 16 Juni 2017

\begin{abstract}
ABSTRAK
Uncaria gambir Roxb. merupakan komoditas tanaman industri yang memiliki nilai ekonomi tinggi serta mempunyai prospek cukup baik bagi petani dan pemasok negara-negara asing. Gambir hasil olahan tradisional (gambir asalan), umumnya memiliki kandungan katekin yang beragam, sehingga diperlukan penanganan lebih lanjut untuk meningkatkan kemurnian katekin dari gambir asalan. Tujuan penelitian adalah untuk mendapatkan teknologi proses pembuatan gambir murni dan katekin terstandar. Sumber bahan baku diperoleh dari proses ekstraksi melalui pengukusan daun dan ranting tanaman gambir (KA) menggunakan peralatan dari aluminium (RA) dan dari besi (RF). Pemurnian gambir asalan melalui ekstraksi berulang dengan air dapat menurunkan kadar tanin, yaitu dari $24 \%$ sampai 2,4\% dan meningkatkan kadar katekin, yaitu antara $40 \%$ sampai $74 \%$. Gambir dengan kandungan tanin rendah (katekin KA) melalui ekstraksi ulang menggunakan air memiliki peningkatan kadar katekin tertinggi dengan warna produk putih kekuningan. Peralatan mengandung besi berpengaruh terhadap warna dari gambir murni yang dihasilkan, yaitu berwarna coklat kemerahan. Pengaruh pelarut terhadap ekstraksi lanjut menggunakan pelarut etil asetat menghasilkan kadar katekin lebih tinggi (sampai 98\%) dibandingkan etanol (95\%). Kemurnian katekin sampel KA diuji dengan melihat stabilitasnya pada berbagai tingkat keasaman, menunjukkan katekin dari gambir stabil pada pH 6.
\end{abstract}

Kata kunci: Gambir asalan, ekstraksi, katekin, tanin, teknologi proses

\begin{abstract}
Uncaria gambir Roxb. is an industrial crop commodity that has a high economic value and good prospect for farmers and exporter. Gambier of traditional processed products (raw gambier) generally have various catechin content, so it is required further handling to increase the purity of catechins from raw gambier. The research was aimed to get a process technology on the making of pure gambier and standardized catechins. Sources of raw materials was obtained from extraction process through steaming leaves and twigs of gambier (KA) using equipment from aluminum (RA) and from iron (RF). Purification of raw gambier through repeated extraction with water could decrease tannin content from $24 \%$ to $2.4 \%$ and increase catechin levels between $40 \%$ to $74 \%$. Gambier with a low tannin content (catechin KA) through re-extraction using water had the highest increase of catechin content with a color of yellowish white product. The iron-containing equipment affected the color of the pure gambier produced, which was reddish-brown. The effect of solvent on further extraction using ethyl acetate solvent resulted in higher catechin content (up to 99\%) compare to ethanol (95\%). The catechin purity of KA samples was tested by looking at its stability at varying levels of acidity, showing catechins of gambier was stabile at $\mathrm{pH} 6$.
\end{abstract}

Keywords: Raw gambier, extraction, pure gambier, catechin, process technology 


\section{PENDAHULUAN}

Uncaria gambir Roxb. merupakan komoditas tanaman industri yang memiliki nilai ekonomi tinggi serta prospek yang baik bagi petani dan pemasok negaranegara asing. Di Indonesia, gambir umumnya digunakan untuk campuran makan sirih, penyamak kulit dan pengobatan tradisional seperti diare. Seiring dengan perkembangan penelitian, gambir dapat dimanfaatkan secara luas dalam industri farmasi, kosmetik, pangan tekstil dan tinta (Muchtar et al., 2008); (Muchtar et al., 2014); (Yeni et al., 2014a); (Ardinal et al., 2014); (Rauf et al., 2015); (Yeni, 2015).

Produk olahan gambir di tingkat petani masih terbatas dalam bentuk ekstrak kering dengan kandungan katekin yang beragam (40-60\%) dan disebut gambir asalan. Pengolahan untuk mendapatkan katekin dipengaruhi oleh bahan baku (daun dan ranting tanaman gambir), peralatan ekstraksi, teknologi proses ekstraksi (suhu dan waktu) dan pengeringan hasil ekstrak (Amos, 2010); (Muchtar et al., 2010); (Yeni et al., 2014a).

Kandungan katekin dalam gambir merupakan karakteristik yang menentukan jenjang mutu gambir. Hal ini disebabkan katekin merupakan substituen utama gambir dengan kebutuhan yang cukup banyak dalam industri dibandingkan tanin. Katekin dalam keadaan murni memberikan rasa manis, berbentuk kristal, berwarna putih sampai kekuningan, sedangkan tanin berasa sepat, berwarna coklat kemerahan sampai kehitaman (Muchtar et al., 2008); (Muchtar et al., 2010); (Yeni et al., 2014a).

Untuk mendapatkan katekin yang tinggi dapat dilakukan melalui proses ekstraksi ulang gambir asalan. Teknologi proses dilakukan berdasarkan perbedaan sifat kelarutan antara katekin dan tanin dalam air. Katekin dalam keadaan murni sulit larut dalam air dingin, mudah larut dalam air panas, larut dalam alkohol dan etil asetat (Muchtar et al., 2010); (Yeni et al., 2014a).

Ekstraksi ulang gambir asalan menggunakan air dapat menghasilkan kadar katekin sampai $80 \%$ (gambir murni) (Muchtar et al., 2010). Produk ini digunakan untuk sediaan industri pangan, tekstil, tinta dan penyamak kulit (Muchtar et al., 2010); (Failisnur and Sofyan, 2014); (Muchtar et al., 2014); (Ardinal et al., 2014). Industri farmasi dan kosmetik berdasarkan persyaratan farmakope membutuhkan katekin dengan tingkat kemurnian besar dari $90 \%$.

Untuk menghasilkan katekin dengan kandungan yang tinggi (katekin terstandar) dapat dilakukan ekstraksi lanjut hasil pencucian ulang dengan air (gambir murni). Penelitian peningkatan kemurnian katekin dari gambir murni sudah dilakukan, yaitu menggunakan kolom amberlit (Muchtar et al., 2008) dan ekstraksi dengan campuran pelarut etanol dan etil asetat, tetapi produk menghasilkan warna yang cendrung gelap (Yeni et al., 2014a).

Penggunaan pelarut dalam mengekstrak senyawa fenolik memberikan perbedaan hasil baik secara kualitatif maupun kuantitatif (Rauf et al., 2010); (Yeni et al., 2014b). Teknologi proses produksi katekin terstandar yang sesuai spesifikasi katekin dibutuhkan perlu dipilih pelarut yang mendekati kepolaran katekin dengan cara proses yang efisien.

Katekin merupakan senyawa yang tidak stabil terhadap pengaruh lingkungan (suhu, oksidasi) (Yeni et al., 2014b). Stabilitas katekin juga dipengaruhi oleh adanya logam yang terdapat dalam ekstrak seperti Fe (Cherrak et al., 2016). Logam dapat berasal dari peralatan dan cara proses yang kurang bersih.

Berdasarkan hal di atas, untuk mendapatkan katekin dari gambir asalan, perlu dilihat faktor-faktor yang berpengaruh. Faktor-faktor tersebut diantaranya bahan baku, teknologi proses ekstraksi ulang, pelarut dan peralatan yang digunakan.

Tujuan penelitian adalah untuk mendapatkan teknologi proses guna menghasilkan gambir murni dan katekin terstandar sesuai kebutuhan industri. Teknologi proses yang dihasilkan diharapkan dapat digunakan sebagai acuan dalam memproduksi gambir murni dan katekin terstandar dari gambir asalan.

\section{METODOLOGI PENELITIAN}

Bahan baku yang digunakan dalam penelitian adalah gambir asalan. Bahan 
proses adalah aquades, etanol, etil asetat. Bahan kimia untuk analisis produk, yaitu bahan untuk analisis katekin (standar katekin, etil asetat); analisis kadar tanin (aquades, folin ciocalteau, sodium carbonat, asam tanat); analisis bahan tak larut dalam alkohol.

Peralatan yang digunakan untuk proses adalah grinder, ayakan 100 dan 200 mesh, peralatan ekstraksi, alat pres dan pengering (spray dryer).

\section{Prosedur Kerja}

\section{Pemilihan bahan baku}

Gambir asalan yang digunakan dalam penelitian ini berasal dari 3 (tiga) sumber petani pengolah di wilayah Sumatera Barat berdasarkan perbedaan cara proses dan peralatan yang digunakan. Proses ekstraksi melalui pengukusan daun dan ranting tanaman gambir, peralatan dari aluminium dinamakan KA. Gambir diproses melalui perebusan menggunakan peralatan dari aluminium (RA) dan peralatan dari besi (RF).

\section{Ekstraksi ulang dengan air}

Ekstraksi ulang gambir asalan dengan air yang dilakukan menggunakan metode (Yeni et al., 2014b). Gambir asalan dihaluskan, dilarutkan dengan aquades suhu $\pm 70^{\circ} \mathrm{C} \quad(1: 5)$ dan disaring menggunakan saringan dengan ukuran bertingkat, yaitu 100 dan 200 mesh.

Filtrat hasil penyaringan dienapkan selama $\pm 20-24$ jam. Endapan yang diperoleh dilanjutkan dengan pencucian ulang menggunakan air dingin sampai diperoleh larutan kekuningan. Endapan yang diperoleh dipres untuk memisahkan air yang tersisa, lalu dikering anginkan atau dikeringkan dengan pengering beku (freezer).

\section{Ekstraksi dengan pelarut organik}

Proses ekstraksi lanjut gambir hasil pencucian dengan air dilakukan menggunakan metode (Yeni et al., 2014b). Gambir murni kering dilarutkan menggunakan etil asetat dan etanol dengan perbandingan 1:10. Larutan gambir dimaserasi \pm 4 jam dan disaring menggunakan saringan 100 mesh. Filtrat yang diperoleh dikeringkan dengan spray dryer pada suhu inlet $=175 \pm 5^{\circ} \mathrm{C}$, suhu outlet $=60 \pm 5^{\circ} \mathrm{C}$ dan laju aliran larutan 20

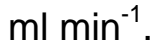

\section{Analisis Sampel}

Sampel bahan baku dikarakterisasi terhadap kadar katekin, kadar tanin, kelarutan dalam air dan alkohol, kadar abu, dan kandungan logam ( $\mathrm{Fe}$ dan $\mathrm{Cu}$ ). Gambir murni dan ekstraksi lanjut dikarakterisasi terhadap kadar katekin, tanin dan stabilitas $(\mathrm{pH})$.

\section{HASIL DAN PEMBAHASAN}

Pengujian gambir asalan dilakukan untuk melihat perubahan komponen gambir (katekin, tanin) setelah dilakukan proses ekstraksi ulang menggunakan air dan ekstraksi lanjut dengan etanol dan etil asetat.

Kadar abu gambir asalan (Tabel 1) menunjukkan jumlah komponen anorganik seperti tanah, pasir yang ikut terbawa pada saat pemanenan dan proses pengolahan tanaman gambir. Hal ini didukung oleh petani pengolah yang umumnya tidak menyaring larutan (filtrat) hasil pengempaan. Filtrat yang diperoleh langsung dialirkan dan ditampung dalam lubang yang terbuat dari tanah. Proses seperti ini menghasilkan kadar abu dari ekstrak yang cukup tinggi (RF dan RA). Untuk sampel KA filtrat sudah ditempatkan pada wadah ember dengan kadar abu yang lebih rendah.

Kadar abu yang tinggi juga dapat disebabkan oleh kandungan logam pada ekstrak gambir. Berdasarkan hasil analisis, kadar Fe tertinggi ditemukan pada sampel RF (Tabel 2), dimana proses perebusan menggunakan kuali dari besi. Logam Fe diduga berasal dari cara proses yang kurang bersih dan peralatan perebusan yang digunakan. Sampel gambir menggunakan peralatan perebusan dari aluminium, yaitu KA dan RA mengandung kadar $\mathrm{Cu}$ yang tinggi. 
Tabel 1. Karakteristik gambir asalan

\begin{tabular}{lcccccc}
\hline Kode gambir & $\begin{array}{c}\text { Kadar air } \\
(\%)\end{array}$ & $\begin{array}{c}\text { Kadar abu } \\
(\%)\end{array}$ & BTL air (\%) & BTL alk. $(\%)$ & $\begin{array}{c}\text { Kadar } \\
\text { katekin }(\%)\end{array}$ & $\begin{array}{c}\text { Kadar tanin } \\
(\%)\end{array}$ \\
\hline Gambir KA & 16,88 & 1,55 & 4,82 & 3,22 & 60,81 & 12,49 \\
\hline Gambir RA & 14,84 & 2,09 & 2,49 & 2,12 & 51,63 & 18,01 \\
\hline Gambir RF & 12,1 & 3,75 & 9,44 & 6,03 & 40,36 & 25,51 \\
\hline
\end{tabular}

Sumber: data penelitian sendiri

Tabel. 2. Hasil analisis kadar logam dari gambir asalan

\begin{tabular}{lcc}
\hline Sampel & $\begin{array}{c}\text { Kadar Fe } \\
(\mathrm{ppm})\end{array}$ & $\begin{array}{c}\text { Kadar Cu } \\
(\mathrm{ppm})\end{array}$ \\
\hline Gambir KA & 80,38 & 11,35 \\
Gambir RA & 76,01 & 93,9 \\
Gambir RF & 275,04 & 8,94 \\
\hline
\end{tabular}

Sumber: data penelitian sendiri

Kadar bahan tak larut (air dan alkohol) menunjukkan besarnya kandungan bahan anorganik hasil ekstrak. Besarnya kadar bahan tak larut dipengaruhi oleh cara proses yang dilakukan. Ekstrak gambir menggunakan proses pengukusan (KA) memiliki bahan tak larut lebih rendah dibandingkan cara perebusan (RA dan RF) (Tabel 1). Hal ini menunjukkan proses perebusan daun dan ranting tanaman gambir dapat membantu meningkatkan kelarutan dari hasil ekstrak.

Kadar tanin yang tinggi berpengaruh terhadap warna hasil ekstrak yang dihasilkan. Tanin yang berwarna coklat sampai kehitaman akan menyulitkan dalam proses pemurnian katekin. Untuk mendapatkan kadar katekin yang tinggi dari ekstrak, kandungan tanin gambir asalan diharapkan dalam jumlah kecil (Yeni, 2015).

Besarnya kandungan katekin dari masing-masing sampel memiliki hubungan yang terbalik dengan kandungan tanin. Semakin tinggi kadar katekin makin rendah kadar tanin yang diperoleh. Kandungan katekin gambir dapat diprediksi dari warnanya, makin hitam warna gambir makin rendah kadar katekin (Gambar 1) (Muchtar et al., 2010); (Yeni et al., 2014b).

Teknologi proses ekstraksi daun dan ranting tanaman gambir yang dilakukan berpengaruh terhadap kandungan katekin yang dihasilkan. Sampel KA dengan cara pengukusan menghasilkan kandungan katekin tertinggi dibandingkan cara perebusan (sampel RA dan RF). Perbedaan kandungan katekin antara sampel RA dan RF dapat disebabkan oleh penggunaan suhu dan lama perebusan daun dan ranting tanaman gambir. Suhu perebusan yang digunakan sulit dikontrol dibandingkan cara pengukusan.

Menurut (Yeni, 2005), semakin tinggi suhu dan makin lama waktu ekstraksi dapat menyebabkan perubahan kandungan katekin menjadi tanin (tanin terkondensasi). Tanin dapat larut dalam air dan kelarutannya semakin besar jika dilarutkan pada suhu tinggi. Ditambahkan (Irianty dan Yenti, 2014), tanin akan terurai menjadi pyrogallol, pyrocatechol dan phloroglucinol bila dipanaskan sampai suhu $98-101^{\circ} \mathrm{C}$.

Bahan baku daun dan ranting tanaman gambir yang digunakan berpengaruh terhadap kandungan katekin yang dihasilkan. Kandungan katekin pada tanaman gambir lebih banyak pada daun sedangkan pada ranting kadar tanin lebih tinggi (Anungputri, 2010). Untuk menghasilkan katekin dengan kemurnian yang tinggi dapat dilakukan dengan pengurangan ranting dalam proses ekstraksi tanaman gambir.

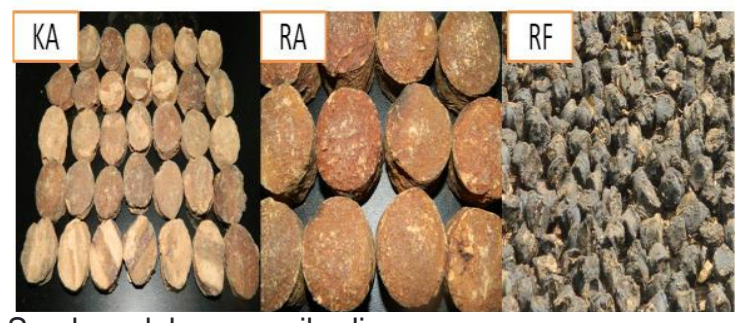

Sumber: dokumen pribadi

Keterangan: $\mathrm{KA}=$ gambir ekstraksi dengan pengukusan dan peralatan dari aluminium, $R A=$ ekstraksi dengan perebusan dan peralatan dari aluminium, RF= ekstraksi dengan perebusan dan peralatan dari besi.

Gambar 1. Penampakan gambir asalan

Peralatan yang digunakan juga berpengaruh terhadap penampakan warna ekstrak gambir. Peralatan perebusan dari besi (RF) (Gambar 1) memiliki penampakan warna ekstrak gambir yang lebih gelap. Hal ini diduga peralatan dari 
besi dapat memicu terjadinya proses oksidasi. Menurut (Cherrak et al., 2016) potensi oksidasi katekin dengan logam $\mathrm{Fe}$ lebih tinggi dari logam lain seperti $\mathrm{Cu}^{2+}$ dan $\mathrm{Mn}^{2+}$.

\section{Pembuatan Gambir Murni}

Pembuatan gambir murni (kadar katekin 80\%-90\%) dilakukan melalui proses ekstraksi ulang gambir asalan dan merupakan tahapan awal proses pembuatan katekin terstandar (kadar katekin > 90\%). Ekstraksi ulang gambir asalan melibatkan proses pemisahan antara senyawa katekin dan tanin yang keduanya merupakan jenis senyawa polifenol.

Pemisahan antara katekin dan tanin dilakukan berdasarkan perbedaan kelarutan antara katekin dan tanin dalam air (Muchtar et al., 2010); (Yeni et al., 2014a). Perbedaan kelarutan katekin dan tanin disebabkan perbedaan kepolaran dari masing-masingnya. Katekin memiliki sifat cenderung semi polar sulit larut dalam air dingin (air bersifat polar).

Katekin dapat larut baik dengan air panas, karena suhu yang tinggi menyebabkan pergerakan partikel dalam pelarut akan menjadi lebih cepat sehingga tumbukan antara partikel pelarut dan zat terlarut menjadi lebih banyak (Yeni, 2015). Melalui proses pengendapan, katekin yang sukar larut dalam air dingin dapat dipisahkan dengan tanin yang masih terlarut dalam air. Pemisahan antara katekin yang mengendap dan tanin yang masih terlarut dalam air dilakukan dengan proses penyaringan.

Tanin adalah senyawa organik yang terdiri dari campuran senyawaan polifenol kompleks, dibangun dari unsur $\mathrm{C}, \mathrm{H}$ dan $\mathrm{O}$ serta sering membentuk molekul besar dengan bobot molekul lebih besar dari 2000. Tanin memiliki sifat dapat larut dalam air atau alkohol karena tanin banyak mengandung fenol yang memiliki gugus $\mathrm{OH}$ (Pambayun et al., 2007); (Irianty dan Yenti, 2014); (Sari et al., 2015).

Pembuatan gambir murni dari gambir asalan, besarnya kandungan tanin dari bahan baku sangat berpengaruh terhadap proses yang dilakukan. Kandungan tanin yang tinggi pada gambir asalan menyebabkan proses ekstraksi akan berulang dan berlangsung lama (Muchtar et al., 2010).

Metode pengeringan yang digunakan juga berpengaruh terhadap perubahan warna hasil ekstraksi ulang. Pengeringan menggunakan oven pada suhu lebih besar dari $50^{\circ} \mathrm{C}$ atau waktu yang lama menghasilkan produk yang kembali berwarna gelap (kecoklatan) (Muchtar et al., 2008). Untuk mengurangi proses degradasi kimia pada katekin selama proses pengeringan, gambir asalan yang sudah diekstraksi ulang dengan air dikeringkan dengan pengering beku (freeze dryer).

Pengujian kadar katekin gambir murni dari 3 (tiga) sumber gambir asalan dengan proses pencucian yang sama terjadi peningkatan untuk semua perlakuan (Tabel 3). Gambir KA memiliki peningkatan kemurnian katekin tertinggi. Hal ini menunjukkan proses ekstraksi dengan pengukusan daun dan ranting tanaman gambir dapat mengurangi degradasi dari katekin dibandingkan dengan cara perebusan.

Berdasarkan Tabel 3, hasil pencucian ulang gambir asalan dengan air menyebabkan terjadi penurunan kadar tanin. Besarnya penurunan kadar tanin bergantung pada kadar tanin gambir asalan yang digunakan dan pengulangan pencucian.

Analisis statistik menunjukkan bahan baku yang digunakan berbeda nyata secara signifikan terhadap perubahan kadar katekin dan tanin hasil ekstraksi ulang gambir asalan $(p<0.05)$. Untuk sampel KA penurunan kadar tanin tidak terlalu signifikan, dimana kadar tanin dari gambir asalan sudah rendah, diduga terdapat tanin terhidrolisis yang sulit dipisahkan dengan katekin (Hagerman, 2005).

Karakteristik fisik gambir murni yang diperoleh dari masing-masing gambir asalan menghasilkan warna yang berbeda (Gambar 2). Warna gambir murni selain dipengaruhi oleh kandungan tanin yang tersisa juga dapat disebabkan oleh kompleks antara logam dengan jenis tanin yang dikandungnya (Yeni, 2015); (Cherrak et al., 2016). 
Tabel 3. Hasil analisis kadar katekin dan tanin gambir hasil pencucian ulang dengan air (gambir murni)

\begin{tabular}{lccc}
\hline \multirow{2}{*}{ Parameter } & \multicolumn{3}{c}{ Gambir murni } \\
\cline { 2 - 4 } & $\mathrm{KA}$ & $\mathrm{RA}$ & $\mathrm{RF}$ \\
\hline Katekin & $74,2 \pm 0,6^{\mathrm{a}}$ & $72,32 \pm 0,2^{\mathrm{a}}$ & $65,61 \pm 1,1^{\mathrm{a}}$ \\
Tanin & $11,32 \pm 0,2^{\mathrm{a}}$ & $12,95 \pm 0,2^{\mathrm{b}}$ & $17,76 \pm 0,1^{\mathrm{b}}$ \\
\hline
\end{tabular}

Sumber: data penelitian sendiri

Kandungan logam $\mathrm{Fe}$ dan $\mathrm{Cu}$ yang terdapat pada gambir, menunjukkan cara proses dan peralatan pengolah yang digunakan berpengaruh terhadap warna produk gambir murni (Gambar 2). Pengaruh logam terhadap warna gambir hasil ekstraksi ulang lebih dominan terlihat. Proses ekstraksi tanaman gambir menggunakan peralatan dari besi (RF) memiliki kadar Fe yang tinggi, sedangkan peralatan proses menggunakan aluminium memiliki kandungan $\mathrm{Cu}$ yang tinggi (Tabel 2).

Gambir asalan dengan kadar Fe tinggi (gambir RF), memiliki warna coklat kemerahan dan kandungan $\mathrm{Fe}$ rendah berwarna kekuningan (gambir KA dan RA). Warna yang dihasilkan dipengaruhi oleh komplek yang terbentuk antara logam dengan senyawa fenol. Semakin tinggi kadar $\mathrm{Fe}$ pada gambir asalan proses oksidasi juga makin tinggi. Hal ini ditunjukkan dengan perubahan warna yang cepat menjadi coklat sampai kehitaman ketika dibiarkan di udara terbuka (Yeni et al., 2014a).

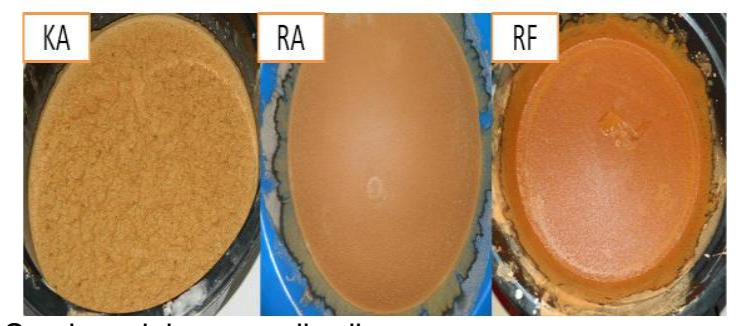

Sumber: dokumen pribadi

Gambar 2. Penampakan gambir murni hasil ekstraksi ulang gambir asalan dengan air (gambir murni)

Menurut (Cherrak et al., 2016), logam seperti $\mathrm{Fe}$ dapat mempengaruhi sifat oksidasi katekin. Aktivitas antioksidan katekin pada emulsi minyak dalam air terhadap keberadaan logam $\mathrm{Fe}$ dan $\mathrm{Cu}$, menunjukkan logam $\mathrm{Fe}$ dapat meningkatkan oksidasi minyak, sedangkan $\mathrm{Cu}$ hanya memiliki pengaruh yang kecil.

Katekin merupakan senyawa polifenol, dimana gugus fenolnya dapat berikatan atau terjadi pengkelatan dengan logam Fe. Kompleks ini mudah teroksidasi dan menyebabkan warna senyawa menjadi gelap (Failisnur dan Sofyan, 2014); (Irianty dan Yenti, 2014). Untuk memproduksi katekin disarankan menggunakan peralatan yang terbuat dari stainless steel atau tembaga.

Kandungan $\mathrm{Fe}$ yang tinggi pada gambir memiliki keuntungan jika gambir digunakan sebagai pewarna, seperti gambir untuk bahan baku tekstil, karena gambir dengan kandungan Fe tinggi dapat menimbulkan warna (Failisnur dan Sofyan, 2014); (Muchtar et al., 2014).

Suhu ekstraksi juga berpengaruh terhadap warna hasil ekstrak yang dihasilkan. Pada proses ekstraksi tanaman gambir, suhu yang tinggi dan waktu yang lama menyebabkan terjadi perubahan komponen katekin dan tanin menjadi polimer tanin. Untuk memproduksi katekin dari gambir, disarankan kontak dengan panas yang berlebihan dihindarkan, sedangkan untuk tanin dilakukan proses yang menggunakan suhu tinggi (Yeni, 2005); (Muchtar et al., 2010).

\section{Ekstraksi Lanjut Gambir Murni dengan Pelarut Organik}

Ekstraksi lanjut gambir murni dengan pelarut organik dilakukan untuk meningkatkan kemurnian katekin. Pelarut yang digunakan dalam penelitian yang memiliki kepolaran berbeda, yaitu etil asetat (semi polar) dan etanol (polar). Penggunaan pelarut yang berbeda dilakukan untuk melihat pengaruh besarnya kandungan katekin yang dapat diekstrak maksimal dari masing-masing pelarut. 
Sifat polaritas pelarut berpengaruh terhadap kecepatan ekstraksi, jenis dan jumlah senyawa aktif yang dapat diekstrak. Senyawa yang memiliki kepolaran yang mirip dengan kepolaran pelarut akan terekstrak, sedangkan senyawa yang kepolarannya berbeda dengan kepolaran pelarut tidak akan terekstrak (Kasim et al., 2013). Menurut (Dewi et al., 2007), untuk mengekstrak senyawa aktif faktor penting adalah penggunaan pelarut yang memiliki kepolaran sesuai dengan kepolaran senyawa yang akan diekstrak.

Metode ekstraksi secara maserasi merupakan teknik yang umum dilakukan untuk mengekstrak senyawa aktif. Metode ini sangat sesuai untuk senyawa aktif yang mudah terdegradasi. Proses ekstraksi secara maserasi dilakukan dengan cara perendaman sampel di dalam pelarut pada suhu kamar dan dapat disertai pengadukan agar senyawa aktif terlarut sempurna (Mandal et al., 2007).

Hasil ekstraksi lanjut gambir murni dikeringkan menggunakan spray dryer. Hal ini bertujuan untuk mengurangi efek kerusakan senyawa aktif terhadap pengaruh panas yang tinggi. Proses pengeringan menggunakan spray dryer dapat dilakukan menggunakan suhu relatif rendah dan proses pengeringan bahan menjadi serbuk terjadi sangat cepat.

Menurut (Masduqi et al., 2014), senyawa fenol memiliki sifat mudah teroksidasi dan sensitif terhadap perlakuan panas. Proses pengeringan dengan suhu tinggi, yaitu lebih tinggi dari $60^{\circ} \mathrm{C}$ dapat merusak dan menurunkan kandungan senyawa fenol.

\section{Pengaruh ekstraksi lanjut terhadap kadar katekin}

Hasil ekstraksi lanjut gambir murni (gambir KA, RA, RF) menunjukkan terjadi peningkatan kadar katekin untuk kedua jenis pelarut (Tabel 4). Penggunaan pelarut etil asetat menghasilkan kadar katekin lebih tinggi dibandingkan pelarut etanol. Sampel hasil ekstraksi cara pengukusan (KA) memiliki kadar katekin tertinggi $( \pm 98.83 \%)$ dengan kadar tanin terendah pada bahan baku. Hal ini menunjukkan senyawa impurities seperti tanin yang terdapat pada bahan baku sangat berpengaruh terhadap kadar katekin yang dihasilkan. Disarankan dalam pembuatan katekin terstandar dari gambir asalan diharapkan memiliki senyawa impurities yang rendah.

Etil asetat merupakan pelarut yang bersifat semi polar yang akan melarutkan senyawa aktif bersifat semi polar dengan intensitas yang lebih banyak. Senyawa yang bersifat polar (flavonoid) dalam intensitas yang sedikit (Houghton and Raman, 1998). Penggunaan pelarut dengan tingkat kepolaran yang sama dengan senyawa aktif selain dapat memaksimalkan hasil juga sebagai efisiensi pengambilan senyawa aktif.

Tabel 4. Pengaruh ekstraksi lanjut gambir murni terhadap peningkatan kadar katekin menggunakan pelarut etil asetat dan etanol

\begin{tabular}{lccc}
\hline \multirow{2}{*}{ Perlakuan } & \multicolumn{3}{c}{ Kadar Katekin (\%) } \\
\cline { 2 - 4 } & KA & RA & RF \\
\hline Gambir ekstraksi dengan etil asetat & $98,83 \pm 0,1^{\mathrm{b}}$ & $97,82 \pm 0,3^{\mathrm{b}}$ & $95,80 \pm 0,2^{\mathrm{c}}$ \\
Gambir ekstraksi dengan etanol & $94,83 \pm 0,4^{\mathrm{a}}$ & $95,92 \pm 0,2^{\mathrm{a}}$ & $93,92 \pm 0,5^{\mathrm{b}}$ \\
\hline
\end{tabular}

Sumber: data penelitian sendiri

\section{Pengaruh ekstraksi lanjut gambir murni terhadap kadar tanin}

Ekstraksi lanjut gambir murni dengan etanol atau etil asetat, terjadi penurunan kandungan tanin. Penurunan kadar tanin terendah pada gambir asalan dengan cara perebusan dan menggunakan alat ekstrak dari besi (RF). Penurunan kadar tanin kemungkinan dapat disebabkan oleh tingginya kandungan logam $\mathrm{Fe}$ pada sampel (Tabel 5).

Berdasarkan Tabel 5, ekstraksi lanjut gambir murni menggunakan etanol menunjukkan penurunan kadar tanin yang rendah dibandingkan pelarut etil asetat. Hal ini disebabkan tanin merupakan senyawa makromolekul dari golongan 
polifenol yang bersifat polar, sehingga proses ekstraksi dapat dilakukan menggunakan pelarut polar (Kasim et al., 2013).

Tabel 5. Pengaruh ekstraksi lanjut gambir murni terhadap penurunan kadar tanin menggunakan pelarut etil asetat dan etanol

\begin{tabular}{lccc}
\hline \multirow{2}{*}{ Perlakuan } & \multicolumn{3}{c}{ Kadar Tanin (\%) } \\
\cline { 2 - 4 } & $\mathrm{KA}$ & $\mathrm{RA}$ & $\mathrm{RF}$ \\
\hline Gambir ekstraksi dengan etil asetat & $1,21 \pm 0,1^{\mathrm{c}}$ & $4,84 \pm 0,1^{\mathrm{c}}$ & $17,36 \pm 0,0^{\mathrm{b}}$ \\
Gambir ekstraksi dengan etanol & $2,35 \pm 0,3^{\mathrm{b}}$ & $3,26 \pm 0,1^{\mathrm{b}}$ & $13,99 \pm 0,1^{\mathrm{a}}$ \\
\hline
\end{tabular}

Sumber: Data hasil penelitian sendiri

Senyawa tanin dapat berperan sebagai pengkelat atau pengompleks logam Fe. Kekuatan pengkelatan bergantung pada jenis tanin dan $\mathrm{pH}$ senyawa fenolik itu sendiri. Jenis tanin terhidrolisis memiliki potensi untuk menjadi pengkelat logam $\mathrm{Fe}$ yang kuat. Kuatnya daya kelat dari senyawa tanin membuat kelat logam menjadi stabil dan menjadi sulit dipisahkan kembali (Hagerman, 2005).

\section{Karakteristik fisik katekin terstandar}

Hasil pengamatan secara visual katekin terstandar (Gambar 3), menunjukkan etil asetat memiliki warna putih kekuningan dan sesuai spesifikasi warna katekin. Hasil ekstraksi dengan etanol menghasilkan warna yang sedikit gelap (kuning kecoklatan).

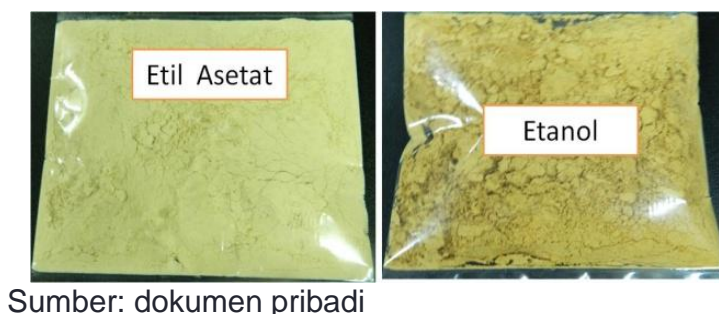

Gambar 3. Hasil pengamatan secara visual hasil ekstraksi lanjut gambir murni menggunakan pelarut etil asetat dan etanol

Etanol merupakan pelarut yang bersifat polar dengan konstanta dielektrik sebesar 24,5 sehingga pelarut ini dapat melarutkan dengan baik senyawa-senyawa yang bersifat polar maupun semi polar, seperti senyawa golongan flavonoid dan tanin (Mandal et al., 2007); (Jain et al., 2009); (Yeni, 2015). Senyawa golongan flavonoid dan tanin yang ikut terekstrak ini dapat menyebabkan produk ekstrak etanol berwarna kuning kecoklatan.

\section{Efek pH terhadap Kemurnian Katekin}

Katekin dari gambir merupakan senyawa fenolik yang memiliki kemampuan sebagai antioksidan. Konsentrasi senyawa fenolik menentukan besarnya aktivitas antioksidan dan berpengaruh terhadap kestabilan zat yang mudah teroksidasi (Dube et al., 2010). Katekin memiliki sifat tidak stabil terhadap $\mathrm{pH}$, suhu oksigen, cahaya yang dapat menyebabkan kerusakan sebagian besar senyawa fenolik (Masduqi et al., 2014). Semakin murni katekin kestabilannya makin rendah, karena senyawa fenol makin banyak.

Pengujian kestabilan katekin terstandar sampel KA dengan kadar katekin tertinggi pada berbagai tingkat keasaman $(\mathrm{pH}$ 2-8) menggunakan spektrofotometer UV-Vis pada panjang gelombang $(\lambda) 279 \mathrm{~nm}$ terjadi perbedaan nilai absorbansi. Konsentrasi absorbansi menunjukkan tingkat stabilitas katekin, dimana makin tinggi absorbansi mengindikasikan makin stabil katekin.

Hasil pengamatan Gambar 4 menunjukkan senyawa katekin lebih stabil pada kondisi asam tinggi ( $\mathrm{pH}$ 6) yang ditunjukkan dengan nilai absorbansi yang tinggi, makin rendah $\mathrm{pH}$ stabilitasnya juga makin rendah. Hal ini dapat disebabkan dalam ekstrak makin banyak $\mathrm{H}+$ bebas, $\mathrm{H}_{+}$ ini dapat meregenerasi senyawa antioksidan dengan cara berikatan dengan radikal fenoksil membentuk senyawa antioksidan kembali (Dewi et al., 2007).

Menurut (Liang and Xu, 2001); (Dewi et al., 2007), katekin menunjukkan aktivitas antioksidatif yang rendah pada $\mathrm{pH}$ 1-5 dan tinggi pada $\mathrm{pH}$ 6-12. Kondisi ini terjadi 
pada senyawa cathecol dan pyrogallol. Aktivitas antioksidatif katekin pada $\mathrm{pH}$ 6-12 mengalami penurunan dengan urutan $\mathrm{EGCG}>\mathrm{ECG} \fallingdotseq \mathrm{EGC}>\mathrm{EC}$. Urutan ini bergantung pada jumlah gugus hidroksil pada masing-masing senyawa.

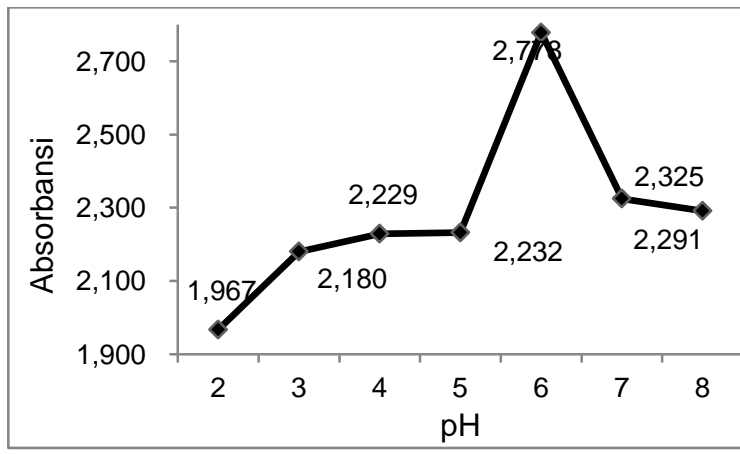

Sumber: data penelitian sendiri

Gambar 4. Grafik hubungan antara tingkat keasaman ( $\mathrm{pH}$ 2-8)) terhadap absorbansi katekin pada panjang gelombang $(\lambda)$ $279 \mathrm{~nm}$

Perubahan aktivitas antioksidatif pada berbagai $\mathrm{pH}$ berkaitan dengan konstanta disosiasi asam $\left(\mathrm{pK}_{\mathrm{a}}\right.$ ) antioksidan. Katekin menunjukkan aktivitas antioksidatif pada nilai $\mathrm{pH}$ yang lebih kecil. Faktor lainnya yang mengatur aktivitas antioksidatif yakni pembentukan radikal fenoksil dan semiquinoid yang stabil sehingga katekin dapat memicu aktivitas antioksidatif pada $\mathrm{pH}$ di atas 5. Aktivitas antioksidatif menurun pada $\mathrm{pH}>12$ akibat pembentukan asam katekinat.

\section{KESIMPULAN}

Teknologi proses ekstraksi ulang dengan air terhadap gambir asalan melalui pengukusan daun dan ranting (sampel KA) menghasilkan peningkatan katekin tertinggi dengan produk bewarna putih kekuningan. Peralatan yang mengandung besi (RF) berpengaruh terhadap warna gambir murni yang dihasilkan, yaitu berwarna cendrung lebih gelap (coklat kemerahan).

Pemurnian gambir asalan melalui ekstraksi berulang dengan air dapat menurunkan kadar tanin $(24 \%$ sampai $2,4 \%$ ) dan meningkatkan kadar katekin (40\% sampai $74 \%$ ). Ekstraksi lanjut dengan pelarut etil asetat menghasilkan kadar katekin tertinggi $( \pm 98 \%)$ dan menunjukkan katekin lebih mendekati kepolaran etil asetat. Kestabilan katekin dengan tingkat kemurnian yang tinggi dapat ditentukan dengan melihat pengaruh tingkat keasaman gambir, dimana katekin murni stabil pada $\mathrm{pH} 6$.

\section{UCAPAN TERIMA KASIH}

Ucapan terima kasih kepada Kementerian Riset dan Teknologi Indonesia untuk bantuan keuangan melalui Insentif SINas tahun Anggaran 2013 dan kepada anggota tim peneliti yang telah membantu pelaksanaan penelitian.

\section{DAFTAR PUSTAKA}

Amos, 2010. Kandungan katekin gambir sentra produksi di Indonesia. J. Stand. 12, 149-155.

Anungputri, P.S., 2010. Kajian pembuatan gambir bubuk dari daun gambir (Uncaria gambir Roxb) kering menggunakan spray dryer. Skripsi TIP IPB Bogor 1-115.

Ardinal, Salmarisya, S., Kasim, A., 2014. Perilaku krom dalam limbah cair penyamakan kombinasi krom-gambir dan krom-mimosa pada penyamakan kulit. J. Litbang Ind. 4, 59-66.

Cherrak, S.A., Mokhtari-soulimane, N., Berroukeche, F., Merzouk, H., Elhabiri, M., Bensenane, B., 2016. In vitro antioxidant versus metal ion chelating properties of flavonoids: A structureactivity investigation. PLoS One 1-21. doi:10.1371/journal.pone.0165575.

Dewi, J.R., Estiasih, T., Murtini, S., 2007. Varietas coklat (Sorghum bicolor) hasil ekstraksi antioxidant activity of extracts obtained by applying various solvents to the local brown sorghum (Sorghum bicolor) Bran. J. Teknol. Pertan. 8, 188-197.

Dube, A., Ng, K., Nicolazzo, J.A., Larson, I., 2010. Effective use of reducing agents and nanoparticle encapsulation in stabilizing catechins in alkaline solution. Food Chem. 122, 662-667. doi:10.1016/j.foodchem.2010.03.027.

Failisnur, Sofyan, 2014. Sifat tahan luntur dan intensitas warna kain sutera dengan pewarna alam gambir 
(Uncaria gambir Roxb) pada kondisi pencelupan dan jenis fiksator yang berbeda. J. Litbang Ind. 4, 1-8.

Hagerman, A., 2005. Tannin handbook. Miami University, Oxford $\mathrm{OH} 45056$ www.users.muohio.edu/hagermae/ [27 Februari 2015].

Houghton, P., Raman, A., 1998. Laboratory handbook for the fractination of natural extracts.

Irianty, R.S., Yenti, S.R., 2014. Pengaruh perbandingan pelarut etanol air terhadap kadar tanin pada sokletasi daun gambir (Uncaria Gambir Roxb). sagu $13,1-7$.

Jain, S., Jain, R., R, S., 2009. Arid zone plants as natural antioxidant agents. J. indian Chem. Soc. 86, 199-201.

Kasim, M.J., Hussin, M.H., Achmad, N., Dahon, H., Suan, K., Hamdan, S., 2013. Determination of Total Phenol, Condensed Tannin and Flavonoid Contents and Antioxidant Activity of Uncaria Gambir Extracts. J. Chem. Inf. Model. 53, 1689-1699. doi:10.1017/ CBO9781107415324.004.

Liang, Y., Xu, Y., 2001. Effect of $\mathrm{pH}$ on cream particle formation and solids extraction yield of black tea. Food Chem. 74, 155-160. doi:10.1016/ S0308-8146(01)00108-X.

Mandal, V., Mohan, Y., Hemalatha, S., 2007. Microwave assisted extraction an innovative and promising extraction tool for medicinal plant research. Pharmacogn. Rev. 1, 7-18.

Masduqi, A.F., Izzati, M., Prihastanti, E., 2014. Efek metode pengeringan terhadap kandungan bahan kimia dalam rumput laut. Bul. Anat. dan Fisiol. XXII, 1-9.

Muchtar, H., Anova, I.T., Ardinal, 2014. Pengaruh penggunaan senyawa pengomplek dan bahan tambahan terhadap mutu tinta pemilu dari ekstrak gambir (Uncaria gambir Roxb). J. Litbang Ind. 4, 89-96.

Muchtar, H., Yeni, G., Hermianti, W., Diza, Y.H., 2010. Pembuatan konsentrat polifenol gambir (Uncaria gambir
Roxb) sebagai bahan antioksidan pangan. J. Ris. Ind. 4, 71-82.

Muchtar, H., Yusmeiarti, Yeni, G., 2008. Pengaruh jenis absorban dalam proses isolasi katechin gambir. J. Ris. Ind. 2, 14-23.

Pambayun, R., Gardjito, M., Sudarmadji, S., Kuswanto, K.R., 2007. Kandungan fenol dan sifat antibakteri dari berbagai jenis ekstrak produk gambir (Uncaria gambir Roxb). Maj. Farm. Indones. 18, 141-146.

Rauf, A., Rahmawaty, Siregar, A.Z., 2015. The Condition of Uncaria gambir Roxb as one of important medicinal plants in north Sumatra Indonesia. Procedia Chem. 14, 3-10. doi:10.1016/j.proche. 2015.03.002.

Rauf, R., Santoso, U., Suparmo, 2010. Aktivitas penangkapan radikal DPPH ekstrak gambir (Uncaria gambir Roxb.). Agritech 30, 1-3.

Sari, P.P., Rita, W.S., Puspawati, N.M., 2015. Indentifikasi dan uji aktivitas senyawa tanin dari ekstrak daun trembesi(Samanea saman(Jacq.) Merr) sebagai anti bakteri Escherichia coli. J. Kim. 9, 27-34.

Yeni, G., 2015. Rekayasa proses nanoenkapsulasi konsentrat katekin dari gambir (Uncaria Gambir Roxb) sebagai antioksidan. Disertasi.

Yeni, G., 2005. Pengaruh pemanasan larutan gambir terhadap perubahan komponen kimia dan kemampuannya sebagai penyamak kulit. Tesis Pasca Sarj. Univ. Andalas.

Yeni, G., Gumbira-Sa'id, E., Syamsu, K., Mardliyati, E., 2014a. Penentuan kondisi terbaik ekstraksi antioksidan dari gambir menggunakan metode respon permukaan. J. Litbang Ind. 4, 39-48.

Yeni, G., Syamsu, K., Suparno, O., Mardliyati, E., Muchtar, H., $2014 b$. Repeated extraction process of raw gambiers (Uncaria gambier Robx.) for the catechin production as an antioxidant. Int. J. Appl. Eng. Res. 9, 24565-24578. 